\title{
PYELITIS IN INFANCY; A Pathological Study.
}

\author{
BY \\ BRUCE CHOWN, M.C., B.A., M.D. \\ Demonstrator in Pediatrics, University of Manitoba. Pathologist to the \\ Children's Hospital, Winnipeg, Canada.
}

(From the Harriet Lane Home of Johns Hopkins Hospital and the Department of Pediatrics of Johns Hopkins University.)

The clinical picture of "pyelitis in infancy" is so familiar to anyone dealing with children, and is so glibly spoken of in text-books and medical journals, that one would imagine the disease had a definitely established pathological basis. This is not the case. It was in an attempt to establish this basis that the present study was undertaken. In the presentation of the data I shall give first the evidence as to the site and nature of the lesion as shown by the pathological observations of previous authors, and by my own studies; then that derived from surgical procedures ; and, finally, the little so far obtained by cystoscopic methods. I shall then deal with less completely certain ætiological factors. The subject has been confined to a discussion of the disease as it occurs in infants of two years and less : cases of obvious congenital malformation and those complicated by stone have been omitted.

\section{Historical.}

Escherich $\left({ }^{1}\right)$ is generally given credit for having first introduced the conception of pyelitis as a clinical entity into pediatrics. Actually he described, in some lectures given in 1895, several cases of pyuria occurring in girls of from seven to nine years of age, and, arguing from analogy to the known condition in adults, he concluded that these were cases of cystitis. The following year Finkelstein $\left({ }^{2}\right)$ reported eight autopsies on infants mostly under one year of age, and deduced from his findings that the lesion present was a primary pyelitis. Yet he reported only one microscopic examination, which, remarkably did not include the renal pelvis. In 1897 Trumpp $\left({ }^{3}\right)$ reported Escherich's cases again and added several of his own, together with autopsies. In only two cases were lesions found in the urinary tract, and in these no microscopic examination was reported.

Following this there was a break of ten years during which controversy raged, but no proof was forthcoming. In 1907 Caccia $\left({ }^{4}\right)$ reported fifteen cases, but only one autopsy. In the brief record it is stated that the patient was a boy of nine months, in whom pyuria accompanied a bronchopneumonia, and that, at autopsy, parenchymatous nephritis and thrombosis of the left renal vein were found. The next year Zahorsky ${ }^{5}$ ) reported a fatal case in a girl of eight months who, at autopsy, showed multiple ulcers of the ureters. No microscopic examination was recorded. In 1909 Thomson $\left({ }^{6}\right)$ reported twenty-five cases; McDonald $\left({ }^{7}\right)$ at the same time describing in great detail the pathological findings in two of Thomson's patients who died. These were two boys of four and seven months respectively. In both cases there were extensive focal and diffuse suppurative lesions in the kidneys, associated with doubtful catarrhal changes in the pelves and ureters, and still less in the bladder. The submucosa of these latter organs showed perivascular mononuclear infiltration. In the first case the lesion was bilateral. In both colon bacilli were present. This is the first clear desiription of the lesion which we possess, but both Thomson and McDonald looked upon these as exceptional cases and missed their true significance. 
The reader is referred to this article for several excellent photomicrographs, and also a good coloured plate of a gross specimen. In the same year West $\left({ }^{8}\right)$ reported a case in a girl of ten months, occurring as a sequel to pneumonia. The microscopic examination was made by McCallum, who reported the condition as being a suppurative nephritis. The renal pelves wero not mentioned.

In 1910 Jeffreys $\left({ }^{9}\right)$ reported sixty cases of bacilluria, with four autopsies in children under two years. The pathological reports were quite incomplete, there being no microscopic record in two, and no mention of the pelves in the other two. That year Thiemich $\left({ }^{10}\right)$ made an important contribution to the subject. Among his cases he reported three autopsies on boys of two and a half, five and a half, and six and a half months, and four on girls of three, five, seven and eight months. In six of these there were found extensive suppurative lesions of both kidneys, together with a normal pelvic mucosa. In some the pelvic submucosa appeared thickened, or contained momonuclear cells in abnormal amount. One showed, in addition, infiltration of the submucosa of the fundus of the bladder with mononuclear cells. In the seventh patient, a girl of seven months, the pathological lesion was confined to the bladder. Four of the six cases with kidney lesions suffered from a preceding upper respiratory infection. Unfortunately Thiemich did not examine the urine or kidneys bacteriologically.

In 1916 Cabot and Crabtree $\left({ }^{11}\right)$, in discussing non-tuberculous kidney infection, mentioned the case of a girl of four months, who post mortem showed apparently a true pyelitis without renal involvement. The bladder and ureters were not mentioned in the protocol.

In 1918 Wieland $\left({ }^{12}\right)$ gave his experience with the pathological findings in the disease. "Unfortunately," he wrote, "the autopsy throws little light on the mode of infection. 'Mild cases can heal without leaving any anatomical trace. We have been able repeatedly to convince ourselves of this by the autopsy of patients who have had a mild pyelitis, and who have'died of some intercurrent disease. Neither macroscopic nor microscopic change could be demonstrated in the pelves or kidneys of these children, which suggested a preceding pyelitis or pyelonephritis. In acute fatal cases the pelves and ureters may show no change, or only a hyperæmia. On the other hand the kidneys are the seat of constant marked changes." He gave details of the lesions he had observed which were the same as those described by McDonald and by Thiemich. Practically the same experience was reported the next year by Rhonheimer $\left({ }^{13}\right)$. Chown $\left({ }^{14}\right)$ reported one fatal case of pyelitis in which no microscopic lesion was demonstrated. The microscopic examination of the pelvis was not reported.

Finally,* to close the subject of autopsies, Helmholtz $\left({ }^{15}\right)$ reported that he had made serial sections of the pelves in cases of clinical pyelitis without being able to discover any inflammatory lesion.

In brief, then, we have complete information in only nine cases of "pyelitis" in infants of two years or less $(7: 10)$. In eight of these there was a suppurative nephritis with insignificant lesions elsewhere in the urinary tract, while in one there was a cystitis alone. The only case on record of pyelitis verified by microscopic examination is that reported by Cabot and Crabtree, and this report is incomplete. Two authors, without reporting their cases in detail, give as their conclusions that, in acute fatal cases of "pyelitis," the kidney uniformly is involved while the pelvis may or may not show lesions.

\section{New Pathological Evidence.}

The data here presented are taken from the records of the Departments of Pediatrics and Pathology at Johns Hopkins Hospital for the years 1911 to

* Drs. O. M. Schloss and J. R. Wilson have an article on the pathology of pyelitis in press (Am. J. Dis. Child.) at the present time. Their conclusions are similar to mine. I wish to express my appreciation of having been allowed the opportunity of going over their sections and protocols and of discussing the problem with them. 
1924. Summaries of the clinical histories and pathological findings are given in all fatal cases of infants in whom the diagnosis of pyelitis, pyelonephritis, or pyelocystitis was made before death, on whom post mortem examinations were performed, or in whom the condition was first found at autopsy. The detailed reports of these cases are contained in the appendix.

The cases are divided into three groups.

Group 1 (cases 1-21) contains those that may be classed as acute or subacute. The striking features are (1) the uniform finding of multiple, focal, interstitial, suppurative lesions in the kidneys; (2) the infrequency of any but the slightest pathological changes in the pelves, and their rarity in the ureters and bladder; (3) the recovery of bacilli of the colon group in all cases where cultures were made (13 out of 21 cases): (4) the association with the infection elsewhere ( 12 of 21 cases) : (5) the equal distribution between the two sexes: and (6) the frequency of bilateral involvement, but with a tendency to more severe lesions on the right side ( 12 bilateral, 6 right sided, 2 left sided, 1 not known).

Group 2 (cases 22-25) shows four cases in which no lesion was found as a souree of the pyuria.

Group 3 (cases 26-29) contains cases with chronic pyuria. These are perhaps the most interesting and instructive of all. Here with chronic pvuria and bacilluria accompanied by persistent marked symptoms or by a very slight general reaction, the pelves again show no source for the pus; while the kidneys are always involved and exhibit both acute, multiple, focal, suppurative lesions and inflammatory lesions in various stages of healing.

(ase 30 is added to show that the condition may go on to complete histologic healing.

\section{(KRoup 1. Acute or Subacute Cases.}

CASE 1. Boy of ten months, acutely ill for nineteen days in October, with symptoms simulating typhoid or meningitis. Pus and colon bacilli in urine. Head not examined at autopsy. Only lesion found was a bilateral, acute, focal and diffuse suppurative nephritis with pus draining from the tubules. No acute inflammation of the pelvis but a few mononuclear cells in the submucosa. Colon bacillus grown from the heart's blood, and a Gram-negative bacillus from the kidney.

CASE 2. Girl of ten months, taken ill in September and dying after one week of acute gastro. intestinal symptoms. Pathological lesion as in Case 1, and in addition a few leucocytes and small round cells in the pelvic mucosa. No bacteriological study. Head not examined at autopsy.

CASE 3. Boy of seven months, taken acutely ill in April with cough and fever. Course seven days. Urine contained albumen, pus, an occasional red blood cell and cast on the fourth day. Pathological lesions found at autopsy, small area of bronchopneumonia, bilateral renal lesions as in Case 1, and a few mononuclear cells in the pelvic and cystic submucosa. Colon bacillus grown from the urine and a staphylococcus from the blood during life.

CASE 4. Boy of ten months, taken ill in September with diarrhœa, sometimes bloody. No dysentery bacilli found in the stool, and no acute inflammatory intestinal lesion discovered at autopsy. Course nineteen days. Colon bacilli grown from the urine during life. Pathological findings; right-sided nephritis as in Case 1, a normal pelvis, a few large round cells and t.wo small hamorrhages in the submucosa of the bladder. 
CASE 5. Girl of six months, taken acutely ill in June with gastro-intestinal symptoms. Course nineteen days. When first seen on the fifteenth day pyuria and colon bacilluria present. Post mortem findings, right sided nephritis as in Case 1 and a normal pelvis.

CASE 6. Boy of three months, ill for five weeks in the summer but with the acute phase lasting only about one week. Onset with " cold." Pyuria present at least two weeks. Renal lesions found at autopsy as in Case 1, with a few round cells in the pelvic submucosa and slight polymorphonuclear infiltration of the mucosa over the tip of one pyramid. Colon bacillus grown from the urine.

CASE 7. Girl of twenty-one months taken ill in July, with otitis media. Course thirty-five days, pyuria present át least two weeks. Terminal bronchopneumonia. Autopsy demonstrated a unilateral (left), suppurative nephritis, with focal and diffuse involvement. No demonstrable lesion in the pelvis, ureter or bladder.

CASE 8. Boy of six months, ill nineteen days in August. Onset with a "shaking chill," followed later by vomiting and loose stools. Pathological lesion found, bilateral nephritis as in Case 1, with slight round cell infiltration of the pelvic submucosa. No cultures.

CASE 9. Girl of thirteen months, ill for sixteen days in July. Clinical suggestion of otitis media but head not' examined post mortem. Pyuria at least seven days. Renal pathological lesions as in Case 1, bilateral. Few mononuclear cells in the pelvic submucosa. No cultures.

(ASE 10. Boy of six months ill twenty-two days in September. Onset with cough. Pyuria at least a week. Blood culture sterile. Colon kacilli grown from the urine before and after death, and from the kidney post mortem. Pathological lesion, the same bilateral suppurative nephritis with a few mononuclear cells in the pelvic submucosa.

CASE 11. Girl of six months, ill six weeks in January and February. Onset with blue spells; later cough. Otitis present at least three weeks, and pyuria at least same length of time. There was found, post mortem, pneumonia and pulmonary abscess, right sided suppurative nephritis as above described, and some mononuclear cells in the pelvic submucosa. No culture.

CASE 12. Boy of twenty-two months, taken ill in August. Course five weeks. Onset with vomiting and diarrhœa. Otorrhœe and pyuria at least two weeks. Colon bacilli grown from blood and urine. Pathological lesions found, enlarged kidneys with pus in collecting tubules, pelves normal.

CASE 13. Boy of two months, ill only two weeks. Onset with cough and fever. Terminal jaundice. Pus in urine on last day (only examination). Post mortem were found early bronchopneumonia, liver necrosias, bilateral suppurative nephritis, and a few mononuclear cells in the pelvic submucosa. Blood culture during life sterile. Post mortem cultures of liver, gall-bladder and spleen sterile. Culture of kidneys, colon bacilli.

CASE 14. Boy of four. Admitted for operation upon a chronic hydrocephalus. Not considered acutely ill. Few white blood cells in the urine. Died during operation. Pathological lesion, acute slight interstitial nephritis, pus draining from collecting tubules. Pelvis normal. I consider this an important case.

CASE 15. Girl of five months, taken ill in March with paroxysmal cough and high fever. First seen after one month of illness. Otitis media, doubtful pneumonia, marked distention of bladder, and pyuria then present. Died eight days later. At autopsy, bronchopneumonia, slight interstitial nephritis with masses of pus in the renal tubules, few mononuclear cells in pelvic submucosa.

CASE 16. Boy of four months, ill with cough for two weeks before admission. No diagnosis on admission; trace of albumen and occasional pus cell in urine. Rapid improvement then sudden relapse. Large number of pus cells in urine, and colon bacilli grown from it. Once more general improvement for two weeks, but pus and bacilli constantly in urine. No fever. Terminal acute diarrhœa for four days. Post mortem, right-sided acute suppurative nephritis with slight perivascular mononuclear infiltration of pelvie submucosa. Left kidney not examined microscopically.

CASE 17. Girl of six months, admitted in March. Otorrhœa for four months. Two weeks ago, pain on micturition. Fever for two weeks : diarrhœa two days. Convulsion on day of admission. Urine, much pus and Gram-negative bacilli, unidentified. Blood culture sterile, 
Died on seventh day in hospital. At autopsy bilateral suppurative nephritis, injection of pelves, ureters and bladder, and many mononuclear cells in the pelvic submucosa.

CASE 18. Boy of six months, admitted in September with an acute bacillary dysentery of one week's duration. Urine, some pus and an occasional red blood cell. On fifth day much pus. Died on seventh day. Pathological lesions, acute, ulcerative colitis ; pus in collecting and convoluted tubules of left kidney. Macroscopic hæmorrhages in pelvic mucosa and submucosa but no pus cells.

CASE 19. Girl of eight months. In hospital for six weeks for malnutrition; doing well ; developed impetiginous lesions of skin, fever, then pyuria and colon bacilluria. These conditions persisted and she died three weeks from onset of illness. Otorrhœa for last three days of life. Autopsy findings :-ulcerative enteritis, cystitis, kinking of right ureter near bladder, exudate (?) in vesical opening of right ureter, dilatation of right ureter and pelvis to a slight degree, mild interstitial nephritis with pus cells in the renal tubules.

CASE 20. Girl of thirteen months, taken ill in January. Course eight days, five from the onset of urinary symptoms. Streptococcus infection of middle ear and probably of blood stream. At autopsy acute, multiple, suppurative focal nephritis, slight infiltration of the pelvic and ureteral mucosa, very considerable infiltration of the submucosa of both these organs, together with some œdema and congestion. Colon bacilli grown from the kidney ; streptococci from the middle ear and heart's blood, while sections of the kidney showed Gram-positive cocci and Gram-negative bacilli. This was the only case that showed pelvic involvementsufficient in itself to have caused a moderate pyuria.

CASE 21. Girl of four and a half months, taken ill in August with gastro-intestinal symptoms and dying at the end of ten days. The finding of old pleural adhesions suggested a previous infection, which was further borne out by the presence of proliferative changes in the kidney. Also present, an acute suppurative nephritis on the right side with a normal pelvis. Gram-negative bacilli in the tubules and glomeruli.

\section{Group 2. (No lesion found).}

CASE 22. Boy of eight months, ill for eight days in September with acute colitis. Seen only on last day, at which time there was a marked pyuria. In the gross, yellow lines were seen running parallel to the striæ of the renal pyramids, but microscopically was found no abnormality beyond a few mononuclear cells in some Bowman's capsules. Pelves normal. The yellow lines were probably areas of suppurative nephritis, but this cannot be proved. No definite source of pus.

CASE 23. Girl of two and a half months. Had never done well. Acutely ill eight days. Albuminuria, cylinduria and pyuria for at least four days. Primary pathological lesion, acute entero-colitis; subsidiary, acute bronchopneumonia and parenchymatous degeneration of the kidneys. No source found for the pyuria.

CASE 24. Boy of two years. Said to have had pneumonia, convulsions and sore throat for three weeks before admission. On entrance to hospital only lesions were chronic otitis media and few leucocytes and casts in the urine. On the sixth day acutely ill. Suppression of urine. Next day albumen, casts and many pus cells. Death same day. At autopsy bronchopneumonia found. The kidneys, pelves, ureters and bladder were normal. No source of pyuria.

CASE 25. Girl of three months. Ill for six weeks, first with nasal discharge and cough, then acute otitis media, and finally bronchopneumonia. Under observation for last three weeks. Kidneys became palpable while in hospital. Urine contained trace of albumen, few leucocytes, many epithelial cells and occasional cast. Colon bacilli grown from it three times. Blood culture sterile. At autopsy neither kidneys nor pelves showed source of pus. Small submucous hæmorrhage of bladder. Colon bacilli and streptococcus fæcalis grown from the kidney post mortem.

\section{GROUP 3. Chronic pyuria.}

CASE 26. Girl of ten months, who had had a cough, and had done badly, for five months, and had had running ears for an indefinite time. On admission there were found a double otitis media, an empyema, and a urine loaded with pus and bacteria. The empyema (bacillus influenzæ, 
Pfeiffer) was drained. Para-colon bacillus grown from urine. The child lived for two months, during which time the temperature was never above $100^{\circ} \mathrm{F}$. The urine was repeatedly the same. Post mortem the kidneys in the gross were passed as merely congested, whereas microscopically, there were leucocytic infiltration along the medullary rays, collections of mononuclear and polymorphonuclear cells in the interstitial tissue of the cortex, irregularly depressed and compressed areas at the surface, and only slight mononuclear infiltration of the pelvic submucosa. The bladder was normal.

CASE 27. Girl of seventeen months. Thirty-nine days before she was brought to the hospital this patient suffered from nausea, distention and occasional vomiting, together with fever that reached $104.5^{\circ} \mathrm{F}$. These symptoms still persisted at the time of admission. The only pathological findings were in the urinary tract. The kidneys reached almost to the crests of the ilia. The bladder was up to the umbilicus. The urine contained albumen, large clumps of pus cells, hyaline and granular casts, and red blood cells. Colon bacilli grown from the urine. Death on the forty-eighth day of illness. At autopsy no lesion was discovered outside the urinary tract. The kidneys were enlarged, contained abscesses, and the capsule on being stripped off carried some bits of kidney tissue with it. The pelves were injected. Microscopically, there was found the usual acute suppurative nephritis, but in addition there were, both in the cortex and in the medulla, areas in the early stages of inflammatory repair. The pelves showed only slight submucous infiltration, as did the ureter and uretero-vesical junction. The bladder was normal.

CASE 28. Boy of seven months, ill for an indefinite period. On admission both kidneys were palpable and the urine contained many pus cells and bacteria and a few red blood cells. Gram-negative bacillus grown from the urine. Death on the ninth day in hospital. Post mortem there was essentially the same picture as in Case 27.

CASE 29. Girl of seven months, admitted in May on account of anuria and œdema of twenty-four hours' duration. Urine contained pus cells in clumps, red blood cells, casts and albumin. Colon bacilli grown from it. Afebrile for four days, then sudden flurry of fever for ten days with an increase in the pyuria. Thereafter well for one month except for an occasional leucocyte in the urine. Sent to a convalescent home, where during her five weeks stay she had several unexplained rises in temperature. Urine repeatedly normal. Finally there was a sudden attack of fever, accompanied by albumen, pus, and casts. She was re-admitted to hospital and died the same day. At autopsy the only gross lesions were two areas in the left kidney suggestive of early abscess formation. Microscopically there was suppurative interstitial nephritis with pus draining from the collecting tubules. In the sections available there was no evidence of any old lesion. The pelves were normal.

CASE 30. A boy of fourteen months developed pyuria while under observation. The severe stage lasted for about two weeks, but there were a few pus cells in the urine for another two and a half months. Five months later he died of pneumonia, at which time there was no pus in the urine. At autopsy the kidneys did not show any scars of old lesions, nor was there any pathological change in the pelves.

\section{Surgical Evidence.}

The surgical evidence is very meagre, but goes to confirm the opinion formed from a pathological study. Jeffreys $\left(^{9}\right)$ reported the case of a girl of six months, admitted to the hospital with meningeal symptoms. Under observation the right kidney enlarged, followed by the left. The right subsided without interference, but the left continued to increase. Finally a left nephrotomy was done, with the release of a large quantity of purulent material. The surface of the kidney showed the mottled appearance, with necrotic areas, as described in the above autopsies. The baby made a good recovery. Watt $\left({ }^{16}\right)$ in 1923, reported the case of a girl of three and a half months suffering from a right-sided suppurative nephritis, who was cured by nephrectomy. There 
was no dilatation of the pelvis, and apparently no obstruction. Unfórtunately no bacteriological studies were made in either of the above cases.

In 1923 I was fortunate in observing a third case*, which occurred on the hospital service of Dr. L. Emmett Holt.

This was a girl of nine and a half months, who was taken ill on December 24th, 1922, with fever, listlessness, and vomiting. She was given castor oil and thereafter her stools were two or three a day. Her temperature ranged between $102^{\circ}$ and $103^{\circ}$. She was very drowsy, and, from December 30, it was noted that she did not move her left arm. She was admitted to the Babies' Hospital on January 2. One's first impression was of an infant in the late stages of tuberculous meningitis. She lay in a semi-stuporous state, but was irritable on being disturbed; the head was turned to the right and retracted; the hands clenched, the arms held stiffly at the sides; the left arm was moved less than the right. There were fleeting flushes. The eyes did not follow a light. Nystagmus and internal strabismus were present. The left knee jerk was marke.lly exaggerated, and there was bilateral ankle clonus. Temperature $105.4^{\circ}$. Leucocytes 11,400, with $75 \%$ polymorphonuclears. The spinal fluid was normal. The only discoverable focus of infection was a pair of small, shallow ulcers of the soft palate, close to the anterior pillars of the fauces. The diagnosis was in doubt. By January 5th the leucocyte count had risen to 19,800. The next day the kidneys were first noted as palpable. The urine contained a moderate trace of albumen, a few epithelial cells, and an occasional leucocyte in the uncentrifuged specimen. For a week the condition progressed, with continually high fever, a mounting leucocyte count, which on January 11 th reached 48,400 , and with the further signs of kidney involvement of œdema, casts and microscopic hæmaturia. On the 13th, a cystoscope was passed by Dr. Bugbee. The bladder and ureteral orifices were normal. The right ureter was catheterized, about one half cubic centimeter of cloudy urine being obtained; and the pelvis was washed with boric acid, foilowed by silver nitrate. A Gram-negative bacillus was grown from this urine. Following this the temperature range was, $100^{\circ}$ to $102^{\circ}$, and the leucocyte count dropped to 10,000 , but the clinical picture remained the same. On January 24 th a cystoscope was again passed. This time no urine was obtained from the right kidney until after washing with boric acid. B. coli communior was grown from the urine so obtained. Again there seemed little clinical improvement. The leucocyte count was now 7,600 ; the temperature curve ran along $100^{\circ}$ to $102^{\circ}$, once reaching $104^{\circ}$. The urine still contained a few pus cells, epithelial cells, and an occasional cast. Finally, as a measure of desperation, operation was decided on. On February 3rd Dr. Bolling exposed the right kidney. It was found to be large, boggy, with several yellowish, depressed areas beneath the capsule. Two of these were explored but no pus found. The pelvis could not be felt to be enlarged. The capsule was split, and stripped from the anterior and lateral half of the kidney, and a hæmostat was passed through the body of the kidney towards the pelvis. There was no gush of urine. Drainage tubes were inserted. Four days later there was noted to be some clinical improvement. Ten days after the operation the temperature reached normal, and on March 10th the baby was discharged as well. The urine up to the time of discharge still contained a few pus cells.

All three of these cases showed kidney involvement associated with pyuria. Only one was studied bacteriologically, and in this B. coli alone was recovered from the urine. In the same case cystoscopy showed no bladder lesion, nor was there any great damming back of pus.

\section{Cystoscopic Evidence.}

Jeffreys $\left({ }^{9}\right)$, in a series of eleven cases, included two little girls, one of 20 months and one 26 months, in both of whom the bladder was normal. Hinman( $\left.{ }^{17}\right)$

* I wish to express my thanks to Dr. H. B. Wilcox for permission to report this case. 
did not give the ages of his patients, so we cannot consider them here. Kretschmer and Helmholtz ${ }^{\left({ }^{18}\right)}$ in their series included three girls under two years of age. In all there was bilateral pyuria and bacilluria. No mention was made of the bladder, but Helmholtz elsewhere $\left({ }^{15}\right)$ says it was inflamed in all cases. Stevens $\left(^{19}\right)$ included one girl of 12 months in his series of 1921. As the bladder had been treated for some time before cystoscopy, the picture of inflammation found must be looked upon with doubt. In a later report $\left({ }^{20}\right)$ he included two cases in girls under one year. One was cystoscoped two weeks after the onset of fever. In the urine from the right kidney a few pus cells but no bacteria were found, from the left colon bacilli, while the bladder urine was sterile. In the second case, a chronic one, he found stricture of the urethra with trabeculation of the bladder, and bilateral bacilluria and pyuria. There was no inflammation of the bladder.

The evidence is somewhat conflicting, and too scanty to be of much value. It points to usual bilateral involvement of the upper urinary tract, with or without inflammation of the bladder. The criteria for the diagnosis of cystitis in these cases is not clear. Stevens' case of stricture of the urethra in a girl of less than one year is interesting and suggestive.

\section{Discussion.}

First let me again point out that this investigation has been limited to a study of pyuria in infants of two years or less. In reading the literature upon the subject of pyelitis in infancy, it is difficult to understand how the concept of primary inflammation of the renal pelvis arose, and how it came to be so generally accepted. But, once accepted, it has been " religiously adhered to as a fundamental axiom." I believe that the current conception of pyelitis is erroneous, leading to error in diagnosis, treatment and investigation. All the evidence available points to the kidney proper as the usual seat of the lesion in cases of pyuria in infancy.

Anyone basing conclusions on the nature of a disease upon dead-house pathology, is at once faced by the possibility that his results may be correct in the fatal cases, but that the pathology is not necessarily the same in the mild ones. While this may be so in the present instance, yet to argue in favour of a primary pyelitis as the pathological basis of mild cases is to speak for something which has never been shown to exist. As against the likelihood of a second type of lesion in the mild cases of pyuria I should.draw attention to the following points. First, in the present series the deaths are not all due to the kidney disease (Cases 11, 14, 18 and possibly 15). Secondly, in Case 14 the disease was of so mild a nature that the child was not considered ill enough to contraindicate operation for a chronic hydrocephalus, yet as the only source of pyuria a minute area of suppurative nephritis was found. Thirdly, in the chronic cases are found old, healing lesions in the kidney side by side with recent, active areas of suppuration. If the pus had been originating in the pelves for the greater part of the time, and the renal involvement were a terminal event, one would expect to find some degree of pyelitis. There is none. And if 
it were argued that with the onset of the renal inflammation the pelvic involvement has healed, one is then at a loss to explain the scars in the kidney.

Further work is necessary to settle the question, but so far it would appear that the common lesion in pyuria in infancy is a suppurative interstitial nephritis, with secondary involvement of the parenchyma. Whether there is a preliminary capillary damage due to toxins or organisms originating in a focus of infection elsewhere, or to vascular stasis or other causes, is not determined; nor do we know if there is a heightened virulence of the associated colon bacilli ; nor yet what part obstruction to the urinary flow may play. The infecting organisms, having gained a foothold in the interstitial tissue, produce an acute inflammatory lesion, characterised by œedema, an outpouring of polymorphonuclear and, to a less extent, mononuclear cells, with degeneration of the neighbouring parenchymatous tissue and varying degrees of necrosis. Necrosis and liquefaction are, however, not prominent findings. The organisms and inflammatory products escape into the tubules, drain thence into the pelvis, and so appear in the urine. The pelvis is apparently very resistant to infection. That bacteria may be taken up here and passed back to the kidney by way of the lymphatics cannot be denied, but that such a thing occurs has not been proven beyond question. Certainly it is extremely rare for an acute inflammatory reaction to occur here, and that such reaction as is seen could be the source of a profuse pyuria seems impossible. It appears rather that in the mild cases the kidney drains and goes on to complete healing. In the more severe cases there are more extensive or more numerous lesions, with insufficient drainage. In the chronic cases there occur repeated infections of the kidney.

The gross appearance of the kidney in this disease varies according to the stage of the disease at which the patient dies. In the earliest cases the kidney, both externally and on section, may appear normal or slightly congested. The pelvis is normal. At a later stage the kidney is found swollen and congested. The degree of swelling is extremely variable, and may be scarcely noticeable, certainly not clinically appreciable. The outer surface usually shows many small, greyish white or yellowish white, flat or slightly depressed areas surrounded by a zone of hæmorrhage. The cut surface bears similar lesions both in the cortex and in the medulla, with some linear ones stretching through the pyramids. The pelvis is usually normal, though sometimes it has appeared congested or the seat of petechiæ. In the next stage abscesses are found in the substance and on the surface. Finally, in the chronic cases, there is a somewhat swollen kidney with a slightly adherent capsule, and with necrotic or suppurative foci as in the previous cases. There are certain cases which run their course without foci becoming visible to the naked eye. In these the kidney is usually swollen, soft and congested, and on section the surface is greyish and slimy.

There can be no doubt that a second type of primary lesion as a source of pyuria occurs, though in this series it has been infrequent. This is an acute glomerulitis, such as was described by Bell and Hartzell (21). It is possible that a certain number of cases looked upon as primarily interstitial might, upon 
further examination, prove to be glomerular, but the gross appearance of the two types is entirely different.

2. With a second prevalent belief relative to "pyelitis" it is impossible to agree; namely, that the disease affects, almost exclusively, female babies. In the early work upon the subject it seems that no attempt was made to be sure that the urine, upon which the diagnosis was based, was uncontaminated. Overlooking the great possibility of such contamination in girls, all cases of pyuria were looked upon as cases of inflammation of the urinary tract, and so there arose the idea of the almost exclusive occurrence of the disease in girls. The error is repeated even up to the present time. There are three main sources of error here. First, and probably most common, is that due to catarrhal vaginitis, itself secondary to some acute febrile condition such as tonsillitis, pneumonia, appendicitis or one of the exanthemata. Second is specific vaginitis, which is frequently associated with urethritis. Third is contamination from the stool in the acute enteritides. Unless all these sources are ruled out, no case can be considered as one of true pyuria, and I know of no large series of cases in which this has been done. It cannot then be said, on the evidence at hand, that the disease is one predominantly affecting one sex.

The idea has become so firmly fixed, however, and is so universally held, that it has of itself led to still further error. If a girl runs a temperature, which is not at once explainable, urinalysis is done in the expectation of finding pus, and so the incidence among girls increases. But on the other hand it is considered so rare in boys, that, in the same circumstances, urinalysis is frequently omitted, and the incidence among boys accordingly decreases.

In the period under consideration there occurred in Harriet Lane Home 105 cases of pyuria under two years of age. Of these 73 were in girls and 32 in boys. Allowing for the above factors of error we are still left with the probability of a predominance in girls. The mortality figures are probably nearer to the true sex distribution, $60 \%$ girls and $40 \%$ boys, but for the present it must be admitted that accurate figures are not available.

Sex must then be considered as a probable ætiological factor, and plays its part in all likelihood, by offering an additional route of infection in girls. It seems very doubtful if infection can ascend through the urethra in male infants. Further, the pathological picture presented in both sexes is usually a definitely interstitial one, suggesting a blood stream infection. In the absence of positive proof it seems reasonable to believe that the route is by way of the blood stream in boys, and in a similar number of cases in girls. In the remaining bilateral cases in girls the assumption of an ascending infection by way of the urethra appears justifiable, and certainly some of the cases of cystitis uncomplicated by a lesion higher in the urinary tract probably originate in this way.

3. To explain the more frequent occurrence of right-sided lesions, the theory of direct lymphatic extension from the cæcum has been invoked( $\left.{ }^{22}\right)$ by Franke. So far as I am aware his original investigations have never been confirmed. In point of fact, in infancy, the left kidney is much more closely connected to the colon than is the right. Very frequently only the lower pole of the right 
kidney is in contact with the large intestine, or there may be no connection whatever. The lower half of the kidney is not more frequently involved in the disease than is the upper. Further the pelvis itself is rarely in direct relation with the colon. There is, however, a difference between the anatomicai relationships of the two kidneys, which may be of importance. The right is overlapped by the liver, which may even reach down and cover the pelvis and renal vessels. In the course of acute infections it is a common occurrence to find the liver greatly enlarged. With the infant lying flat on its back this might well bring pressure to bear on the right kidney with some consequent stasis and lowering of resistance. Helmholtz and Field $\left.{ }^{(23}\right)$ have recently demonstrated that complete occlusion of the renal vein for as short a time as three minutes so alters the kidney permeability as to permit bacteria to pass through in a very short space of time. The liver further keeps the right kidney at a lower level than the left. Whether this is due to the kidney being pushed down or prevented from rising up during fotal life I am not sure, but in either case this would offer a greater opportunity for ureteral kinking on the right. In a small series of cases I have observed multiple, small kinks of the first part of the ureter in young infants. I cannot say that they have been more often right sided, nor have they been, as a rule, associated with any disease of the kidney. Whether they have any significance is uncertain.

4. Upon two other ætiological factors the present study throws some light. The first is the bacterial agent involved. In all cases reported here in which a bacteriological study was made a bacillus of the colon group was found. The significance of this cannot be determined at present. We do not know if it was the sole bacterium, or if it was only a secondary invader. In one case a Gram-positive coccus was found in the kidney sections in association with Gram-negative bacilli, while only B. coli was grown from the urine. While it is possible that on culture B. coli might overgrow other pathogenic organisms, yet to believe that it would do so uniformly is asking a good deal. The assumption that this occurs is not justifiable until further proof is forthcoming. It is also possible that the kidney successfully overcomes some primary invader, only to lay itself open to a later attack. The fact that Thiemich( ${ }^{(10)}$ did not study his cases bacteriologically has been held to vitiate his conclusions, and the finding of abscesses in the cortex in his cases has been adduced as evidence of infection by one of the coccus group. Our present study goes to confirm Thiemich's belief.

The second apparent ætiological factor to which attention is called is that of infection elsewhere. This has been repeatedly observed by other authors. In this series parenteral infections have been somewhat more frequent than enteral, nor have the kidney lesions in the latter cases been particularly severe. Studying the seasonal incidence in the larger group of all cases occurring in the hospital it is found that there are two distinct maxima, one in February and March, and a much higher one in August and September. These correspond with the periods of respiratory infection and of intestinal disturbance. 
5. Finally attention is drawn to certain appearances which have led to incorrect diagnoses of inflammation of the urinary tract. The mucosa of the bladder, ureters and pelves is shed very rapidly after death. We have seen the ureter so filled with desquamated epithelium that it appeared as though blocked with exudate, and we have repeatedly examined turbid urine from the pelves, believing that we were dealing with cases of pyelitis, only to find that the turbidity was due to epithelial cells.

Macroscopically this desquamation may lead to the erroneous diagnosis of catarrhal inflammation. Another error is that of taking the deep red discoloration of the urethra, which occurs post mortem, for evidence of inflammation. Macroscopic diagnosis of inflammation of the urinary tract mucosa after death is of little value.

The question has often been asked "What is the relation between pyelitis of infancy and pyelitis of pregnancy?" Might we not better inquire "What is the relation of the pyurias of infancy to the nephritis of later life?"

\section{Conclusions.}

1. The term "pyelitis of infancy" is a misnomer.

2. The microscopic lesions found in this investigation agree with those found by previous observers.

3. The common lesion is a multiple, focal, suppurative, interstitial nephritis, with which is associated occasionally some degree of pyelitis, and rarely cystitis.

4. The lesion is usually bilateral, but when it is unilateral it is more often right-sided than left-sided.

5. Rarely the lesion found is an acute glomerulitis, or a cystitis.

6. Pyelitis as a sole lesion seldom, if ever, occurs.

7. The lesions described are probably more frequent in girls than in boys.

8. The commonly associated bacterium is probably the Bacillus coli.

9. The renal lesions are usually secondary to an inflammatory process elsewhere.

I wish to express my thanks to Dr. John Howland and to Dr. W. G. MacCallum for placing their departmental records at my disposal for the purpose of this study. 


\section{BIBLIOGRAPHY.}

1. Escherich, quoted by Trumpp, Jahrb. f. Kinderh., Berlin, 1897, XLIV, 268.

2. Finkelstein, H., Ibid., 1896, XLIII, 148.

3. Trumpp, J., Ibid., 1897, XLIV, 268.

4. Caccia, G., Arch. de Méd., Enf. Paris, 1907, X, 705.

5. Zahorsky, J., Pediatrics, N.Y., 1908, XX, 543.

6. Thomson, J., Quart. J. Med., Oxf., 1909-10, III, 251.

7. MeDonald, S., Ibid.

8. West, J. P., Arch. Ped., N.Y., 1909, XXVI, 213.

9. Jeffreys, W. M., Quart. J. Med., Oxf., 1910-11, IV, 267.

10. Thiemich, M., Jahrb. f. Kinderh., Berlin, 1910, LXXII, 243.

11. Cabot, H. and Crabtree, E. G., Surg. Gyn. Onst., Chic., 1916, XXIII, 495.

12. Wieland, E., Cor-Bl.f. schweitz Aertze, 1918, XLVIII, 33 \& 68.

13. Rhonheimer, E., Ibid., 1919, XLIX, 1929.

14. Chown, G., Can. Med. Assn. J., Toronto, 1924, XIV, 115.

15. Helmholtz, H. F., Am. J. Dis. Child., Chic., 1921, XX, 606.

16. Watt, G. H., J. Med. Ass. Georgia, Atlanta, 1923, XII, 410.

17. Hinman, F., Am. J. Dis. Child., Chic. 1919, XVII, 303.

18. Kretschmer, H. L. and Helmholtz, H. F., J. Amer. Med. Ass., Chic,. 1920, LXXV, 1303.

19. Stevens, W. E., Ibid., 1921, LXXVII, 1081.

20. Stevens, W. E., Ibid., 1923, LXXXi, 1919.

21. Bell, E. T. and Hartzell, T. B., Arch. Int. Med., Chic., 1922, XXIX, 768.

22. Franke, C., Mitt.a.d.Grenzgeb.d.Med.u.Chir., Jena, 1910-11, XXII, 623.

23. Helmholtz, H. F. and Field, R. S., Am. J. Dis. Child., Chic., 1925, XXIX, 645.

\section{APPENDIX.}

\section{Casegs in Detail.}

\section{GrouP I.}

CASE 1. Boy, 10 months, admitted in October. Five days ago, feverish. Next day, hands shook. Third day, vomited, and bowels moved only with castor oil. Fourth and fifth days, attacks in which feet trembled, hands clenched, eyes rolled up, and he tended to throw head to right. Temperature $101^{\circ}$ to $104^{\circ}$. Appetite good to fourth day. Water freely taken. In hospital : knees drawn up, arms thrown over face, continual tremors, irritability, impression of great pain. Neck not rigid, knee jerks hyperactive, bilateral Babinski's sign. No other localizing signs. Temperature $103.2^{\circ}$. W.B.C. 37,000; polymorphs $73 \%$. Spinal fluid normal. Urine, pus and colon bacilli. He passed from irritability to drowsiness, and finally stupor. Urine repeatedly the same. W.B.C. 26,000 to 40,000 . Ninth day in hospital, refusing food. Twelfth œdema. Fourteenth, phthalein a trace. Death. Autopsy. Head not examined. Lungs and intestines normal. Kidneys : right, 125 grams, very soft. Capsule strips easily. - Surface nodular due to pin-head size, yellowish white areas, standing out from redder kidney substance ; small hæmorrhages. On section various portions blurred, and in cortex and medulla small yellowish areas and hæmorrhages. Pelvis filled with a cloudy material, but on scraping it away mucosa smooth and glistening. No injection and no hæmorrhage here or in ureter. Left, 65 grams, but similar appearance. Also one soft pale yellow, raised area, $1 \times 2 \mathrm{~cm}$., wedge shaped on section, its centre fluid. Microscopic. Pale areas of œdematous tissue with widely spaced tubules and no cellular infiltration alternate with darker areas made up of polymorphonuclear cells and hæmorrhage and a few tubules with degenerated epithelium. Lumen of tubules stuffed with polymorphonuclear cells and a few mononuclear and red blood cells. Hyaline changes in glomeruli and some red cells in the capsular space. In the medulla, general polymorphonuclear infiltration and tubules dilated with pus. Pelvic mucosa ragged but no signs of acute inflammation; in submucosa groups of mononuclear cells. Ureter and bladder normal. 
CASE 2. Girl, 10 months, admitted September. "Born with a cold," For one week vomiting and diarrhœa. Died one hour after admission. Autopsy. Head not examined. Intestines, some "cloudy swelling and round cell infiltration." Kidneys together 50 grams ; petechiæ. Irregular yellowish patches of same consistency as intervening renal tissue scattered over surface. On section yellowish areas and hæmorrhages extend from outer margin of cortex along tubules into pyramids. Pelves slightly congested. In ureters clumps of white material. Bladder congested and roughened. Microscopic. Interstitial tissue of cortex in part normal; again slight polymorphonuclear infiltration; in other areas dense collections of these cells surrounded by zones of congestion. No leucocytes in glomeruli ; a few in some convoluted tubules ; masses of pus in collecting tubules. In pelvic mucosa an occasional leucocyte or small round cell. Submucosa, mild infiltration with mononuclear cells, especially about blood vessels. Bladder submucosa slightly congested.

CASE 3. Boy, 7 months, admitted in April. Four days ago cough and high fever. On admission general appearance suggested acute meningitis. Pharynx red; abdomen markedly distended; temperature $103^{\circ}$; urine, marked trace of albumen, many pus cells, occasional red blood cells and granular casts. Spinal fluid normal. Third day, urine alkaline, phthalein $15 \%$. Fifth day a staphylocoecus (type not stated) grown from blood, B. coli from urine. Urine on this day, albumen, no pus. Died same day. Temperature always above $101^{\circ}$, usually over $102^{\circ}$, and had reached $104^{\circ}$. Autopsy. Head not examined. Small area of bronchopneumonia. Intestines normal. Kidneys: soft, capsule strips easily; surface pale yellow with numerous small, poorly defined areas of a more pronounced yellowish colour, a few pale grey areas, and a few minute hæmorrhages are scattered it. Cut surface pale; numerous poorly defined streaks running parallel to striæ of cortex and pyramids, no definite abscesses. Turbid fluid in pelvis ; several petechiæ in mucosa. Bladder and urethra normal. Microscopic. In interstitial tissue larger and smaller clumps of inflammatory cells. Glomeruli, no infiltration. Pus and red blood cells in many tubules. Pelvic mucosa poorly preserved but no infiltration. In submucosa possibly some mononuclear increase. Bladder similar.

CASE 4. Boy, 10 months, admitted in September. Two weeks, loose stools ; three days, blood in stools. No vomiting. Appetite poor. On admission no significant clinical signs. Urine, trace of albumen, marked acetone, and pus. T. $101^{\circ}$. W.B.C. 11,600. Stool, no dysentery bacilli. Temperature increased from day to day, fluctuating widely. Stools, blood. Urine on second day, and daily thereafter, pus, hyaline, granular, and cell casts. B. coli grown from urine. Third day, phthalein 47\%. Died fifth day, after a series of convulsions. Autopsy. Head not examined. Intestines, few petechiæ, and some swelling of lymphoid tissue. Right kidney, 39 grams. Capsule strips readily. In middle of lateral border two areas about $7 \mathrm{~mm}$. in diameter dark red in colour, and containing several yellowish spots ; wedge shaped on section, extending to pyramids. Renal detail blurred. Pelvis granular and slightly injected. Ureters normal. Left kidney : 40 grams. ; no gross foci, otherwise kidney and pelvis like right. Microscopic. Left kidney; cloudy swelling. Right kidney : cloudy swelling and congestion, many minute collections of leucocytes in interstitial tissue, with necrosis of neighbouring tubules; one large area of polymorphonuclear infiltration and necrosis in medulla and one in cortex; collecting tubules stuffed with pus; pelvic mucosa normal, and submucosa slightly congested. Bladder mucosa somewhat shredded; in submucosa, a few large round cells, and two small hæmorrhages.

CASE 5. Girl, 6 months. Onset in June. First day, restless, irritable, vomited three times. Next day, high fever. Thereafter anorexia and diarrhœa. Admitted fifteenth day, very ill. Neck slightly rigid ; abdomen distended ; liver easily palpable ; in right iliac and lumbar region a firm, immovable, apparently painless mass. Urine, much pus, no casts. B. coli grown from it. W. B. C. 45,$000 ; 85 \%$ polymorphonuclears. Blood culture sterile. Spinal fluid normal. Diarrhœea and distension persisted. Temperature $100^{\circ}$ to $105^{\circ}$. Fourth day, comatose, at times convulsive; death. Autopsy. Head not examined. Only lesions in urinary tract. Right kidney : 80 grams; numerous irregular, yellowish areas on external and cut surface. Pelvic mucosa pale, no injection. Left kidney, 75 grams; mottled; vessels at base of pyramids injected. Pelvis normal. Microscopic. Right kidney : interstitial tissue generally infiltrated 
with polymorphonuclear cells; abscesses in cortex ; epithelial necrosis. Pelvis not shown. Left kidney : œdema ; pink-staining substance in tubules ; glomeruli, pelvic mucosa and submucosa normal. Bladder mucosa and muscularis normal ; slight perivascular infiltration of submucosa.

CASE 6. Boy, three months, admitted in November. Three weeks ago, spell in which held breath and turned blue, but not rigid. Week later, similar spell; arms stiffly flexed and head retracted. Past two weeks, attacks as often as eight a day. Past week, a cold, and six days, a rash. Appetite good, stools normal. On admission not acutely ill; dry, scaly skin with some pustules ; general glandular enlargement ; T. $97^{\circ}$; W.B.C. 12,400. Urine, trace of albumen, few leucocytes. Wassermann negative. Erb's sign negative. Attacks were "like the breath holding spells of older children." For four days temperature normal. Fourth day : urine, many epithelial cells, few leucocytes. Refused food, vomited. Seventh day, temperature $102.5^{\circ}$, the highest point while in hospital. Urine, albumen, clumps of pus cells. Phthalein $20 \%$. Temperature slowly fell, but condition became worse. Diarrhœa and vomiting developed. Tenth day : urine, marked albumen, many hyaline and granular easts, many pus cells. Died on twelfth day. Autopsy. Head not examined. Lungs and intestines normal. Right kidney : 11 grams; capsule strips with ease; on external and cut surface numerous circumscribed and confluent, opaque white areas, no hæmorrhages. Pelvic mucosa delicate, pale grey, glistening. Ureter normal. Left kidney, same as right. Bladder and urethra normal. Microscopic. At periphery of cortex, wedge shaped areas of polymorphonuclear infiltration alternating with relatively normal tissue. Glomeruli swollen but no infiltration. Tubular degeneration. Many convoluted and collecting tubules filled with pus. Interstitial tissue of medulla much less involved than cortex. Mucosa of pelvis normal ; in submucosa a few round cells. Slight polymorphonuclear infiltration of mucosa over tip of one pyramid. Ureteral mucosa normal; muscularis congested; in submucosa a few polymorphonuclears. Urine culture :-B. coli communis.

CAsE 7. Girl, 21 months, admitted in July. July lst acute otitis media, retention of urine, pain on micturition; urine negative. Seen in dispensary July 17 ; refusing food, feverish, irritable. Admitted July 23 : injected pharynx, dull ear drums, pus and albumen in urine, $T$. $105^{\circ}$, W.B.C. 26,000. Thereafter temperature $100^{\circ}$ to $105^{\circ}$, more often above than below $103^{\circ}$. July 29 : phthalein $30 \%$; blood culture sterile; cough. August 2 ; urine, pus and few casts. August 4 : ear drums ruptured; Widal negative; child restless and twitching; œedema of ankles and eyelids. Next day, abdomen distended; convulsions; death. Autopsy. Head not opened. Small area of lobular pneumonia. Intestines normal. Right kidney : 70 grams; externally and on section normal. Left kidney 105 grams; abnormally firm; abscesses on surface ; on section, an area near anterior pole where grey lines extend through medulla and cortex to end in a conglomerate abscess. Mucosa of pelvis congested. Ureter, no obstruction. Microscopic. Interstitial tissue variously involved; in cortex general infiltration and in two places, necrosis ; in medulla, œdema, moderate infiltration, congestion with hæmorrhage. Glomeruli normal, except in necrotic areas. Convoluted and straight tubules degenerated, and contain pus cells, small and large round cells, and casts. In one pyramid, an extensive localized area of infiltration, none towards tip. Pelvis normal. Epithelium of ureter desquamated, and a minute area of small cell infiltration at one point. Bladder normal.

CASE 8. Boy, 6 months, admitted in August. Fifteen days ago, "shaking chill," followed by high fever. Similar chill next day. "Feverish" two or three days. Bowels became loose tenth to fifteenth day, thirteenth to fifteenth blood in stool. On admission critically ill ; buttocks severely excoriated; T. $101^{\circ}$; W.B.C. 52,700; urine, marked albumen, few casts, many pus cells. No dysentery bacilli in stool culture. Following day, T. $100^{\circ}$ to $100.9^{\circ}$; W.B.C. 48,800 “ Urine, same. Fourth day, convulsions and death. Autopsy. Head not examined. Beginning bronchopneumonia. Intestines normal. Fascia surrounding kidneys œedematous. Kidneys together 65 grams. Capsules strip easily. Kidneys studded with creamy coloured areas, irregular in size and contour, chiefly in cortex. Pelvis congested, and filled with cloudy fluid containing cream coloured flecks. Ureters normal. Microscopic. In cortex alternating areas of polymorphonuclear infiltration destroying tubules and glomeruli alike, and of cloudy swelling without infiltration. Some glomeruli in latter areas more cellular than normal. Many collecting tubules filled with pus. Epithelium over pyramids, and that lining pelvis intact. Slight round sell infiltration of pelvic submucosa, and of deep muscular layer of bladder. 
CASE 9. Girl, 13 months, admitted in July. Nine days ago, restless. Next day refused part of food, and vomited. Fourth day, temperature $104^{\circ}$; range thereafter $98.6-104^{\circ}$. Two stools a day ; no more vomiting; at times quite distended; no pain on voiding. Eighth day, chill or convulsion. On admission : T. $104^{\circ}$; pale, irritable, hyperæsthetic ; right ear drum slightly reddened; urine, pus no casts ; W.B.C. 28,000. Refused food and water, was nauseated and frequently vomited. Fourth day temperature normal; other symptoms continued. Died on seventh day. Autopsy. Head not examined. Congestion and lymphoid hyperplasia of intestines. Kidneys together 100 grams; deep red, with irregular, yellowish areas scattered over surface, on section fine yellow streaks lead from these areas towards deep red bases of pyramids; tips of latter pale. Ureters and pelves normal. Microscopic. In cortex, areas of dense polymorphonuclear infiltration and hæmorrhage, and some actual abscess formation with necrosis. Pus in many tubules. Pelvic mucosa normal; groups of mononuclear cells in submucosa.

CASE 10. Boy, 10 months, admitted in August. For two weeks, cough and fever, stools green, no vomiting. On admission : no localizing pathological signs ; T. $100^{\circ}$; W.B.C. 40,000 ; urine, trace of albumen, few granular casts, large quantity of pus, culture B. coli ; spinal fluid normal; blood culture sterile. Loose stools and pyrexia continued. Temperature not above 101.5. Terminal bronchopneumonia. Died on eighth day. Autopsy. Head not examined. Intestines normal. Right kidney, 45 grams ; capsule strips easily; foci on surface, in cortex and less in pyramids; yellow lines running through latter. In pelvis few c.c. turbid fluid ; mucosa congested. Ureter not distended; mucosa congested. Left kidney 40 grams, resembles right, Bladder normal. No urethral obstruction. Microscopic. Large abscesses not seen. In many tubules debris, large round cells and polymorphonuclears. Patchy infiltration of interstitial tissue with leucocytes and round cells. Similar cells in pelvis but mucosa normal. Small perivascular collections of round cells in peripelvic tissue. Slight congestion of ureter and bladder. Bacteriological ; heart's blood sterile ; kidney, B. coli communior ; urine, B. coli communior.

CASE 11. Girl, 6 months, admitted in January. Three weeks ago cried out during night, rolled head from side to side, and stiffened out. Four similar turns in first twenty-four hours, after which she seemed well. Week later blue spells during which she felt cold. For four days before admission, high fever, cough, green stools. On admission attack similar to those at onset; T. $104^{\circ}$; neck stiff; urine, much pus ; otitis media. Repeated spells of cyanosis. Died in about two weeks. Terminal pneumonia. Autopsy. Head not examined. Bronchopneumonia and lung abscess present. Intestines normal. Kidneys, twelve grams each. Left kidney, pelvis, and ureter normal. Right kidney : capsule slightly adherent; surface mottled grey and red, and similar patches in cortex and medulla; pelvic mucosa smooth, but a few hæmorrhagic flecks present. Right ureter somewhat dilated near the bladder, mucosa pale and smooth. Bladder moderately distended; mucosa normal. Microscopic. Left kidney, no definite lesion. Right kidney ; capsule normal ; interstitial tissue patchy, mononuclear and polymorphonuclear cellular increase ; masses of these cells in some tubules; pelvic mucosa normal ; ome mononuclear cells in submucosa, and more in peripelvic fat, mainly perivascular.

CASE 12. Boy, 22 months, admitted in August. Three weeks ago acute vomiting and diarrhœa. Vomiting stopped, but diarrhœa continued. Not "feverish." On admission : dehydration; otorrhœa ; indefinite signs in chest ; T. $102^{\circ}$; W.B.C. 12,800 ; urine, pus. Right kidney became palpable under observation. B. coli grown from blood and from urine. Temperature range, first week $98.6^{\circ}$ to $102^{\circ}$, second $102^{\circ}$ to $105^{\circ}$. Death on sixteenth day. Autopsy. Record of organs other than urinary tract mislaid. Temperature curve suggested a pneumonia. Kidneys together 100 grams. Urinary tract normal throughout. Microscopic. Glomeruli normal. Few areas of infiltration interstitial tissue. Cloudy swelling. Clump of pus cells in tubules. Pelvic mucosa and submucosa normal. Bladder normal.

CASE 13. Boy, age 2 months. For two weeks cough and fever. Two days ago, jaundice appeared and same day had a convulsion. On admission only definite findings pyuria and jaundice. Blood culture sterile. Autopsy. Head not examined. Beginning bronchopneumonia. Liver necrosis. Kidneys : 60 grams each; capsule removed with ease; surface smooth, and interspersed with small, round, greyish areas. On section : cortex swollen; striations regular; 
small greyish points scattered through cortex, and extend as streaks into the pyramids as far as calyx. Pelvis normal. Microscopic. Capsule uninvolved. Interstitial tissue œdematous, and infiltrated with inflammatory cells. Masses of pus in distended tubules from periphery to pelvis, more marked at periphery. Pelvic mucosa normal, round cell infiltration of submucosa at angles of reflection. Bladder mucosa and muscularis normal. Few small groups of large round cells in submucosa. Bacteriology : liver, gall-bladder, and spleen, sterile ; kidneys, B. coli.

CASE 14. Boy of four. Admitted for operation on a chronic hydrocephalus. Temperature $101^{\circ}$ : few pus cells in urine; not considered acutely ill. Died during operation. Autopsy. Kidneys normal. Microscopic. Minute area of polymorphonuclear infiltration of interstitial tissue ; pus draining from collecting tubules ; pelvis normal.

CASE 15. Girl 5 months, onset in March. One month ago paroxysmal cough, frequently followed by vomiting; high fever; listlessness and apathy. After six days vomiting stopped, other symptoms continued. In hospital : right ear drum red and bulging; pharynx congested; râles over right lung; liver, spleen and kidneys palpable ; bladder to umbilicus, and urine could be expressed. Urine pus only. W.B.C. 32,000. Sixth day respirations more rapid, and temperature higher. Eighth day, death. Autopsy. Head not examined. Moderate bronchopneumonia. Intestines normal. Kidneys : 50 grams each; capsule strips easily ; external surface smooth, glistening, greyish red ; cut surface, dull, pasty, greyish red, with yellowish points throughout cortex and fine lines through pyramids; few petechiæ. Pelvis not dilated, but mucosa injected, and few petechiæ. Ureters same. Bladder distended, and mucosa congested. Microscopic. Glomeruli congested; some unduly cellular ; occasionally one or two large mononuclear cells free in the capsular space. Some tubules collapsed; others slightly dilated by granular pink substance; others contained pus. A few small hæmorrhages. Most of pclvic mucosa shed off ; remaining part normal. In submucosa a few large mononuclear cells. Similar condition in beginning of ureter. Bladder normal.

CASE 16. Boy, 4 months, admitted in May. Cough for two weeks. For two days loose stools, vomiting and listlessness. In hospital, irritable, but no localizing signs ; T. $98.6^{\circ}$; W.B.C. 16,000 ; urine, trace of albumen, occasional pus cell. Rallied quickly, and for three days appetite good, stools improved, and temperature only once above normal. Fourth to seventh day, apathetic, and uttered shrill cries; T. $100.5^{\circ}$ to $101.5^{\circ}$; urine, pus. Blood culture sterile ; urine, B. coli. Seventh to twenty-second day in hospital temperature normal, general condition improved, urine always loaded with pus, and B. coli grown from it. Phthalein 45 to 50 per cent. On twenty-second day fever and frequent stools, and in four days he was dead. Autopsy, Head not examined. Lungs and intestines normal. Left kidney ; 22 grams ; normal. Right 20 grams; on section a small amount of slimy fluid oozes out ; many small yellow flecks scattered here and there. Microscopic. Right kidney only examined. In some sections generalized infiltration with mononuclear and polymorphonuclear cells, with a pink staining hyaline material in some glomeruli and tubules, and clumps of cells in others. In other sections focal accumulations of cells, mainly mononuclear in type, and submucous infiltration with similar cells at the tip of a papilla. Pelvic mucosa normal with slight perivascular infiltration of submucosa.

CASE 17. Girl 6 months, admitted in March. At two months, dermatitis, furunculosis, and otitis, and thereafter otorrhea off and on. Two weeks ago cried when voided, and was feverish. Fever continued. Two days ago, diarrhœea. Next day temperature higher. On day of admission convulsive attack. On admission T. $103.6^{\circ}$, and that night rose to $105^{\circ}$; ear drums slightly injected ; abdomen distended ; W.B.C. 29,000 ; urine, pus only. Gram-negative bacillus grown from the urine. Blood culture twice sterile. Phthalein $24 \%$ on day of admission, $16 \%$ on sixth day. Death on seventh day, preceded by convulsions and abdominal distention. Autopsy. Head not examined. Small areas of bronchopneumonia. Kidneys : 70 grams each ; not so firm as usual ; capsule strips easily; surface smooth and mottled with areas of brown and yellow; striæ distorted by small yellow zones. Pelves and ureters mildly injected, but no exudate. Bladder injected, and a few hæmorrhages. Microscopic. Interstitial tissue extensively infiltrated, mainly with round cells, relatively few polymorphonuclears. Many glomeruli and tubules destroyed by this infiltration; in other tubules, masses of these cells. Pelvic mucosa ragged, many mononuclear cells in submucosa. Ureter same. Bladder, submucous congestion, 
CASE 18. Boy six months, admitted in September. Bloody diarrhœa, and vomiting for sne week. On admission acute bacillary dysentery,and bilateral otitis media; T. $100.5^{\circ}$; W.B.C. 9,300 ; urine, two or three pus cells per high power field, and occasional red cell. Fifth day : urine, many pus cells and few red cells. Died on seventh day. Autopsy. Ulcerative colitis present. Kidneys together 35 grams; normal externally and on section. Right pelvis normal ; left of normal size, but filled with 1 c.c. of thin, grey fluid. Mucosa dull, congested, and, particularly about the tips of the pyramids, infiltrated with petechiæ. Left ureter normal in size ; mucosa dull, and few petechiæ. Bladder and urethra normal. Microscopic. Right kidney, cloudy swelling. Left : interstitial tissue congested; convoluted tubules degenerated, clumps of cells, mostly polymorphonuclears, in a few ; more pus in collecting tubules. Pelvis, no inflammatory cells, but submucous hæmorrhage.

CASE 19. Girl 8 months, admitted in August. After six weeks treatment in hospital for malnutrition began to run irregular fever, reaching $103.4^{\circ}$ on third day. On same day impetiginoid skin lesions first noticed. W.B.C. 26,000. Urine, heavy sediment of pus. B. coli grown from urine. Temperature from now on irregularly elevated rarely above $101^{\circ}$, never over $103^{\circ}$. Three days before death right otorrhea. Died three weeks from onset of fever. Autopsy. Head not examined. Ulcerative enteritis present. Kidneys externally and on section normal. Right pelvis slightly larger than normal, injected and contains small amount of cloudy material. Right ureter dilated to about size of lead pencil, and injected. Small plug of exudate (?) in uretero-vesical opening. Lower end of ureter, $2 \mathrm{~cm}$. from bladder, sharply kinked, but dilated below this. Left pelvis and ureter normal. Bladder mucosa injected, and trigone covered by diphtheritic exudate. No urethral obstruction. Microscopic. Small collections of polymorphonuclear cells in interstitial tissue, some encroaching upon tubules. Few polymorphonuclear leucocytes in some collecting tubules. Glomeruli congested. No sections of pelvis ureters, or bladder available for study.

CaSe 20. Girl, 13 months admitted in January. Eight days ago a little fever, and slight regurgitation. In a day or two, screamed in sleep as though in pain; ear drums said to be normal; few pus cells and blood cells in urine. Fifth day, ear drums inflamed; some cough ; a good deal of discomfort; fever continued. Next day ear-drums incised without benefit to patient ; T. $104^{\circ}$; stuporous. Lumbar puncture attempted at home without success. Admitted eighth day and died in a few hours, while optochin was being injected intraspinally. Right otorrhea; left drum opened with liberation of pus. W.B.C. 20,000. Urine not obtained. Autopsy. No meningitis, but a recent intracranial hæmorrhage, possibly due to first lumbar puncture. Lungs and intestines normal. Kidneys : right 65 grams, left 60 ; capsule strips easily ; about thirty, yellowish white, slightly raised, roughly circular, necrotic looking areas of various size, but averaging about $2 \mathrm{~mm}$. in diameter both over surface and on section. Ureters dilated, and deep red. Bladder normal. Microscopic. Complete cross sections of kidney with pelvis and piece of ureter obtained. Under hand lens there was seen in ureter and less marked in pelvis a dark line deep to mucosa about $0.2 \mathrm{~mm}$. wide. In cortex were five areas of a similar dark colour, two circular, with lines running to surface, and three wedge shaped with base at surface.

With higher magnifications ureter was seen to contain some exudate, both cellular and structureless, together with Gram-negative bacilli and gram-positive diplococci. Cells mostly polymorphonuclears, with a scattering of large and small mononuclears. Mucosal surface intact save at one point near pelvis, where there was a small area of disintegration, probably a post mortem change. In substance of mucosa were a few leucocytes and round cells. Submucosa and muscularis œdematous, and infiltrated with mononuclear cells and a few leucocytes. These cells, tending toward linear distribution in deep submucosa, formed the dark line seen under the hand lens. Occasionally they were grouped about a blood vessel, the vessels themselves being very congested.

Passing to the pelvis the œdema lessened. The cellular zone approached nearer the surface, in places was extremely dense, and proportion of polymorphonuclear cells in it increased. For the most part the pelvic mucosa showed very slight infiltration with leucocytes. Over the tip of a pyramid most of the mucosa was gone, while here and there were leucocytes adhering to the surface so exposed. It was impossible to say whether this was an artefact or not, but it did not suggest it very strongly. Close by was an area of marked infiltration of the mucosa. 
In kidney, a good deal of infiltration at points where large blood vessels entered. In the papillæ the interstitial tissue at the very tip showed a few infiltrating cells; most tubules empty ; occasional one filled with exudate and a few bacteria. About $2 \mathrm{~mm}$. from this comparatively free tip all was chaos. An occasional tubule could still be seen, but for the most part the picture was one of necrosis and hæmorrhage. Throughout medulla generally there was interstitial infiltration, with here and there sharply marked off foci. . In cortex, degeneration of epithelium and granular exudate in tubules and in some glomeruli, with here and there fairly well localized, large and small abscesses surrounded by hæmorrhage. Predominant cell polymorphonuclear. Bacteriology. Right ear culture :-Streptococcus hæmolyticus. Heart's blood culture :Streptococcus hæmolyticus. Ureter culture :-B. coli communis. Ureter smear :-Few Grampositive and Gram-negative bacilli.

CASE 21. Girl, $4 \frac{1}{2}$ months, admitted in August. August 1st, acutely ill with fever, vomiting and diarrhœa. Admitted on the fifth, and died five days later. Continuous fever ; at times $105^{\circ}$. Voided well, but no urinalysis report available. Autopsy. Head not examined. Old pleural adhesions and a beginning fibrino-purulent peritonitis (probably simply a sterile reaction). Kidneys : right 32 grams; swollen and grey; raised areas, each about $2 \mathrm{~mm}$. in diameter on surface, surrounded by and infiltrated with hæmorrhage. On section these descend into cortex to medulla, which is streaked with yellowish lines. Pelvis injected and pyramids hæmorrhagic. Left 23 grams, firmer, and red; normal on section. Bladder normal. Microscopic. Right : small subcapsular hæmorrhage. (Edema of the interstitial tissue with beginning proliferation. In a few glomeruli increased cullularity of tuft, or capsular space contained a few round cells or leucocytes. Still less commonly, slight proliferation of Bowman's capsule. Near periphery many tubules choked with leucocytes, red blood cells, and mononuclear cells. Pelvic mucosa normal. No submucous infiltration. Innumerable Gram-negative bacilli in the tubules ; a few in the glomeruli. Left : in an occasional glomerulus some increased cellularity due to round cells; in some such cases a few similar cells in a neighbouring tubule. Otherwise negative.

\section{GROUP II.}

CASE 22. Boy, 8 months, admitted in September. Acute diarrhœa on September 13th. Admitted September 20 , and died next day. T. $102^{\circ}$ to $104.2^{\circ}$. W.B.C. 16,000 . Urine loaded with pus. Autopsy. Head not examined. Acute colitis present. Kidneys together 25.6 grams ; externally normal; on cut surface yellowish lines parallel to the striæ in pyramids but not extending into cortex; no abscesses. Pelvis slightly congested. Bladder normal. Microscopic. Some glomeruli normal ; others congested ; still others unduly cellular owing to an accumulation of mononuclear cells, some free in the capsular spaces. Cells of lining epithelium of Bowman's capsule swollen in some cases. No cells in tubules. Pelvic mucosa, submucosa, and muscularis, and peripelvic tissues normal. Occasional minute collection of round cells in submucosa of ureter. Bladder normal. Bacteriology. Both pelves, B. coli.

Case 23. Girl, $2 \frac{1}{2}$ months. Admitted in September. Had never thriven, but no recent change. On admission malnutrition ; congestion of ear drums ; T. $99^{\circ}$; W.B.C. 11,900 ; urine not examined. A few hours after admission the temperature $105.6^{\circ}$, and range thereafter $100^{\circ}$ and $106^{\circ}$. Fourth day; urine, trace of albumen, many hyaline, granular, pus, and cell casts. leucocytes, and urinary tract epithelial cells. Died eighth day. Autopsy. Head not examined. Acute entero-colitis, and bronchopneumonia. Kidneys, 27 grams each ; external and on section normal. Pelves slightly injected. Ureters and urethra patent. Bladder, slight injection of fundus. Microscopic. Congestion and cloudy swelling, with hyaline material in some tubules. Slight perivascular infiltration in pelvis. Ureter and bladder normal.

CASE 24. Boy, age 2 years. For three weeks " pneumonia, convulsions and sore throat." On admission not very ill ; rachitic ; lung signs indefinite; chronic left otitis media; T. $100^{\circ}$; W.B.C. 3,800 ; urine, few pus cells, granular and cellular casts. Condition same for six days. Seventh day refused food, vomited. Suppression of urine. Next day ; urine, albumen, granular and cellular casts, and numerous pus cells ; W.B.C. 21,000. Died that night. Temperature only twice up to $102^{\circ}$. Autopsy. Head not examined. Bronchopneumonia present. Kidneys; 
20 grams each ; externally and on section normal. Right pelvis and ureter moderately hyperæmic. Bladder mucosa hyperæmic about trigone. Microscopic. Slight hyperæmia and cedema. Pelvis, ureter, and bladder normal.

CaSE 25. Girl, age three months. Had never thrived; loose, green stools; vomited occasionally. For three weeks nasal discharge and cough. On admission; malnutrition, nasal discharge and cough ; T. $99^{\circ}$; W.B.C. 7,100. Second day : T. $104^{\circ}$; acute otitis media. Third day; paracentesis ; W.B.C. 9,100 ; left kidney now palpable; urine, trace of albumen, few leucocytes, many epithelial cells, occasional cast. B. coli grown from urine, and again on sixth and seventeenth days. Eleventh day : both kidneys palpable; strabismus ; persistent vomiting. Spinal fluid normal. Blood culture sterile. Fifteenth day : distention. Phthalein on eighteenth day $21 \%$. Died next day. Throughout, temperature ranged widely, becoming higher from eleventh day on. Urine never more than a few leucocytes. Autopsy. Moderately extensive bronchopneumonia. Kidneys together 38 grams; normal. Pelves normal. Microscopic. Extreme congestion, minute blue granules in the interstitial tissue ; no infiltration; no cells in tubules. Pelvic and ureteral mucosa and submucosa normal. Bladder, patchy congestion of submucosa, and one small hæmorrhage. Over latter point mucosa had been shed off. Bacteriology. Kidney, B. coli communis and streptococcus fæcalis.

\section{Group III.}

CASE 26. Girl, 10 months, admitted in June. Cough, and had done badly for five months and otorrhea for indefinite period. On admission malnutrition, double otitis media, empyæma, urine, loaded with pus. Empyema drained (bacillus influenzæ, Pfeiffer). Urine, para-colon bacillus. Two months in hospital; rarely any fever, never above $100^{\circ}$; urine always same. Autopsy. Head not examined. Chronic empyema, pneumonia, myocarditis present. Kidneys together 60 grams; normal except for congestion. Pelvis normal. Ureter somewhat dilated, but mucosa normal. Bladder distended, but mucosa normal. Microscopic. Block 1 : glomeruli normal ; cortex very slightly involved; large areas of leucocytic infiltration along medullary rays ; tubular degeneration; pelvis not seen. Block 2 : glomeruli normal; small collections of mononuclear cells and polymorphonuclear leucocytes in interstitial tissue : some tubules crowded with pus cells ; slight round cell infiltration of the submucosa of pelvis. Block 3 : glomeruli normal ; here and there in interstitial tissue of cortex foci of cells, varying in number from half a dozen to two or three hundred, the chief cell type a large, round cell, with an irregularly ovoid, vesicular nucleus ; tubular degeneration ; pelvic mucosa ragged, and largely shed off, at angle of reflection submucosa extensively infiltrated with cells similar to those in interstitial tissue of cortex. Block 4 : appeared to be process of healing; contour of surface rolling,each roll representing a zone of normal glomeruli, granular, empty, dilated tubules, and normal interstitial tissue, while in depressions, glomeruli smaller than in intervening zones, yet no definite change, tubules compressed, and lumina filled with a homogenous substance, interstitial tissue infiltrated with round cells with some tendency to focal accumulation : pelvic mucosa and submucosa normal. Bladder normal.

CASE 27. Girl, 17 months, admitted in August. Thirty-nine days ago, nausea, distention, occasional vomiting, fever at times $104.5^{\circ}$. Symptoms persisted, and there were added, irritability, hyperæsthesia, and some looseness of the stools. No cold or cough, nor any urinary symptoms. In hospital : irritable ; recent loss of weight ; ears and chest normal ; abdomen slightly distended ; kidneys almost to crests of ilia, soft, irregular not tender; bladder almost to umbilicus ; urine, albumen, pus, hyaline and cellular casts, red blood cells; B. coli grown from it ; T. $101^{\circ}$; W.B.C. 22,800 ; phthalein $15 \%$. Died on the ninth day. Temperature range $99^{\circ}$ to $101^{\circ}$. and once $102^{\circ}$. Urine, pus on all examinations. Autopsy. Head not examined. No pathological lesion outside urinary tract. Kidneys 80 grams each ; flabby ; capsule strips fairly easily, but carries some bits of kidney tissue with it; surface pale red, studded with minute hæmorrhages, small groups of abscesses, and areas of loss of substance; on section, abscesses largely restricted to surface, a few in renal columns; many tubules distended with pus ; pyramids quite red. Pelvis deeply injected, but no pus. Ureters slightly distended and rough. Bladder greatly distended. 
and vessels engorged. Walls of urethra injected. Microscopic. Block 1: capsule normal; interstitial tissue œdematous, and, in medulla, congested and slightly infiltrated with small mononuclear cells; glomeruli congested, some containing hyaline globules; tubular epithelium swollen; pelvic mucosa normal, while submucosa contained a few small and large round cells immediately below the epithelium, and more marked collections about the blood vessels. Block 2 : in addition to above, one triangular area about $0.5 \mathrm{~cm}$. wide of tremendous polymorphonuclear infiltration and of necrosis, bulging surface and extending to tip of calyx. Block 3 : several smaller and more diffuse areas of polymorphonuclear infiltration; many tubules filled with pus. Block 4 : Capsule had been stripped off, and appeared to have carried away some kidney tissue at certain points. Travelling along cortex one passed through a zone in which tubules were dilated but empty, glomeruli appeared unduly cellular, and contained the same hyaline masses seen in other sections, but with no cells in the capsular space, and the interstitial tissue showed a slight increase in small mononuclear cells. Next came a zone of more marked infiltration, congested glomeruli, and smaller tubules with more degenerated epithelium. This formed a boundary to an area of complete disintegration, where nothing remained but a few scattered wandering cells in a granular structureless mass. There were three such zones of disintegration in the section, each just visible to the naked eye. Running through the medulla from the deeper border of these areas towards the pelvis, were three narrow strips of a pinkish, structureless nature, in which the tubular elements lay far apart, and through which were growing young fibroblasts. In addition there were clumps of small round cells scattered through the medulla. The pelvic mucosa was normal, the submucosa shọing the same changes as were seen in other blocks. The mucosa of the beginning of the ureter had been shed off. There was submucous hæmorrhage, and rather more marked infiltration. A section of the ureter from farther along its course showed a normal mucosa with perivascular infiltration of the submucosa. The lumen contained inflammatory debris, in which at least $90 \%$ of the cells were polymor. phonuclears. A section of the uretero-vesical junction showed some irregularity of the mucosa, with slight submucous round cell infiltration. Section of the bladder and of the vesico-urethral junction showed only mucosal irregularity.

CASE 28. Boy, 7 months, admitted in February. For several days baby had been drowsy, and had vomited. On admission : malnutrition; convulsive movements of hands and feet; kidneys palpable but not considered enlarged; T. $104^{\circ}$; W.B.C. 23,600 ; urine, pus and few red blood cells; Culture of urine, gram-negative bacillus. Phthalein $56 \%$. Vomiting increased; T. $100^{\circ}-105^{\circ}$. Died on ninth day. Autopsy. Small area of lobular pneumonia. Head not examined. Kidneys : 40 grams each ; capsule strips casily ; surface pale with numerous yellowish white, slightly irregular, and slightly raised areas ; cortex pale, glomeruli not seen ; striations regular in cortex, but in pyramids disturbed by roundish, yellowish white, opaque patches; pelvis smooth and delicate, and no sign of inflammation. Ureters normal. Microscopic. Block 1 : congestion and cloudy swelling. Block 2 : slight increase in the mononuclear cells in the interstitial tissue. Block 3 : glomeruli congested, an occasional one containing one or two red blood cells or a mononuclear cell in the capsular space; pelvic mucosa irregular, submucosa congested ; small submucous hæmorrhage over tip of a papilla. Block 4 : area of polymorphonuclear and round cell infiltration running through pyramid parallel to tubules. Block 5 : slight congestion, no acute inflammatory foci, and, for the greater part of section slight degree of tubular dilatation, especially in cortex, with flattening of epithelium; three areas just visible to the naked eye, two in cortex, and one in medulla, where tissue appeared more condensed than elsewhere; tubules here collapsed, an occasional one containing a small amount of homogeneous pink substance. Interstitial tissue increased by presence of old, and young fibroblasts, and small round cells with a dark staining nucleus; one cortical area at the surface, which was here depressed; in the other cortical area two glomeruli showed slight epithelial proliferation. One collecting tubule near tip of papilla contained a mass of cells, approximately $70 \%$ being large cells with a large vesicular nucleus, $25 \%$ polymorphonuclear leucocytes, and $5 \%$ small cells with a dark staining nucleus.

CASE 29. Girl, 7 months, admitted in May. Had not voided for twenty-four hours, face, hands and feet swollen. On admission : moderate cedema of hands and feet : ear drums slightly 
injected ; T. 98.6 ; urine, albumen, pus cells in clumps, red blood cells, and casts. B. coli grown from urine. Phthalein $45 \%$. W. B.C. 13,000. Afebrile for four days; oedema decreased; urine approached normal. Temperature then began to rise. Fifth day, W.B.C 1 17,500; wedema marked; pyuria increased; diarrhoea set in. On thirteenth and fourteenth days T. $105^{\circ}$. Temperature rapidly subsided, odema cleared up, and baby appeared well. Remained in hospital another month, during which time urine showed only an occasional leucocyte. Went to a convalescent home. During five weeks there had otitis media for a few days, and from time to time an unexplained rise in temperature. Urine normal. Then temperature to $104^{\circ}$; urine contained albumen, pus, and casts ; W.B.(.. 29,500. Readmitted to hospital, and died the same day. Her death took place three months from her first admission to hospital. Autopsy. Head not examined. Lungs and intestines normal. Left kidney 20 grams; renal substance, pelvis and ureter normal. Right kidney : in pyramid of lower pole a yellowish area measuring $2 \times 7$ $\mathrm{mm}$., and in posterior half of kidney a small, circular, reddish elevated, area about $6 \mathrm{~mm}$. in diameter, and of uniform consistency, neither hard nor soft. Microscopic. Glomeruli congested. Clumps of leucocytes in collecting tubules. In one section an area about $1 \mathrm{~mm}$. in diameter of intense polymorphonuclear infiltration in cortex. Only evidences of interstitial involvement in the remaining sections were a few groups of small round cells. Pelvic mucosa and submucosa normal.

CASE 30. Boy of 22 months. At 14 months admitted to hospital with congenital lues. Urine normal. T. $99^{\circ}$ to $100^{\circ}$. W.B.C. 21,000 . A few days later, cough and high fever. Urine normal, chest negative. Temperature high for twelve days, and during this time urine first showed albumen, with many mononuclear cells and a few polymorphonuclears then many pus cells. (Edema developed, which persisted about nine days. Temperature then fell, and urine cleared up, though for two and a half months there were always a few cells. He was discharged from hospital, did well for five months, then developed pneumonia, was brought to the hospital, and died there. Autopsy. Lobar pneumonia. Kidneys, normal, pelves and bladder. Microscopic. No scarring. Pelvic mucosa submucosa and muscularis normal. Peripelvic fat contained an increased number of mononuclear cells. 